\title{
Performing Tuwhare - Hone Tuwhare: A Biography
}

Reviewed by Simone Drichel, Victoria University, Wellington/Freiburg

\author{
Hone Tuwhare: A Biography \\ Janet HuntAuckland: Godwit, 1998.
}

I hate being stuck up here, glaciated, hard all over and with my guts removed: my old lady is not going to like it ...

For Hone Tuwhare's biographer, Janet Hunt, these words-the opening words of his well-known poem 'To a Maori figure cast in bronze outside the Chief Post Office, Auckland' (1972) -must have reverberated as a powerful warning, reminding her in no uncertain terms that like his 'Maori figure', Hone did not wish to be put on a pedestal as a larger-than-life monument, but sought a representation that allowed him to keep his 'guts', that re-presented his very physical and 'real' presence.

A guideline though they might have offered her, these warning words also made her task rather difficult, for Tuwhare's living and breathing 'presence' could not easily be re-presented. According to Hunt, Tuwhare, 'like Maui, ... inhabits a shifting and multiple identity' (7) that forever escapes the focusing lens of the biographer:

Every time I meet someone who has known Tuwhare, I realise that each of his many friends has a version of him that is uniquely their own. And every time I meet or speak with him, I realise again the impossibility of translating this real, flesh-and-blood, larger-than-life human personality, in its rich diversity, contrariness and depth, into ciphers on a page. (8)

Given the difficulty of the task, Hunt has done a superb job. Instead of producing a conventional celebratory biography, she has written-or assembled -what she aptly calls an 'auto/biography'. Hone Tuwhare is held together by Hunt's biographical framework, but fleshed out by the voice of the poet in countless poems, interviews, letters and notes.

Kōtare 2, no. 2 (1999), pp. 74-77. 
Like many Maori of his generation, Tuwhare grew up the hard way, surrounded by poverty and a Pakeha ideology of assimilation that forced Maori to renounce their own cultural identity. Motherless from the age of five, he lived with his father in ever-changing circumstances as the country slid into a depression. Schooling was irregular, but thanks to a keen interest in reading Tuwhare graduated from primary school as top of the class in English. However, as there was no money for further education, Tuwhare had to leave school and learn a trade, instead. He became a boilermaker-a profession that kept him in bread and butter for most of his life.

Though in his early years Tuwhare was surrounded by te reo Maori, he was soon discouraged from speaking the language, because his father Ben-like so many others at the time-'believed that English was the language of the future for his son' (28).

Tuwhare's poetic beginnings similarly display an unquestioning acceptance of an assumed European superiority. In one of the most memorable anecdotes in the book, Tuwhare relates how the poet R.A.K. Mason, a fellow member of the Communist Party, inspired him to try a few verses himself:

Having freed himself from these constraints, Tuwhare set out to find and refine his own poetic voice. Hunt guides the reader through the major events, both real-life and literary, in the remarkable journey of this emerging Maori poet. From Hunt, the biographer, we learn about his trips overseas as a boilermaker, the break-up of his marriage, his son's schizophrenia, and finally, his countless trips overseas as a poet. And from Hunt, the scholar, we also learn about Tuwhare's poetry and are given a critical assessment of individual collections. Each of Tuwhare's ten collections is given due attention, from his first collection, No Ordinary Sun (1964), - - reprinted a sensational eleven times-to his most recent one, Shape-Shifter (1997), - winner of the 1998 Montana Award for poetry. Thanks to both this attention to his publications and a number of indepth, thematically grouped discussions of individual poems, Hone Tuwhare offers not just the usual biographical context for Tuwhare's work, but also serves as a splendid introduction to the poetry itself.

The book is beautifully produced (following Hunt's own design). The choice of colours - black, white and a few touches of red - subtly underlines Tuwhare's Maori identity. The wide margins left by the main text are utilised in two ways: firstly for the aforementioned thematic discussions of individual poems and secondly for the 'auto'-part of this 'auto/biography': numerous reproductions of photos, poems, first drafts, notes and other important documents from Tuwhare's life.

Kōtare 2, no. 2 (1999), pp. 74-77. 
As a reader, I initially found these margins and their diversions from the 'main' narrative rather frustrating, because they kept interrupting the flow of my reading. However, I have since come to appreciate these interruptions as yet another of Hunt's strategies to bring Hone's own voice to the fore, and thereby recreate for the reader an experience of his life and personality. This sense that Hone's life is being offered to us to experience is even more striking, when we take into consideration that the very process (of interrupting the main narrative) mimetically reproduces Hunt's own experience of the poet, such as she described it in an interview with lain Sharp:

He would go off on a tangent and I would try to steer him back to the original question ... But when I listened to the tapes later I found he was often heading in a more interesting direction anyway. So I decided it was best just to let him talk, putting in occasional comments of my own to keep the flow going. (Sunday Star-Times 22 Nov. 1999, p. D2)

How much easier it would have been for Hunt to gloss over all those ramblings and diversions and create a coherent, linear narrative celebrating the life of one of Aotearoa/New Zealand's favourite poets; how much easier in other words, to 'cast him in bronze' and put him up on a pedestal for us all to look at. Yet Hunt decided to pay tribute not only to Tuwhare's life and poetry, but also to his personality. The result is an auto/biography in which Tuwhare is indeed allowed to keep his 'guts'. The book, as Hunt rightly points out, 'is thus a platform for another Tuwhare performance', allowing Hone what his 'Maori figure cast in bronze' was refused, namely to step down from the pedestal that elevates (and thus separates) him from what he most longs to be part of-life itself:

If only I could move from this bloody pedestal l'd show the long-hairs how to knock out a tune on the souped-up guitar, my mere quivering, my taiaha held at the high port. And l'd fix the ripe kotiros too with their mini-piupiu -ed bums twinkling: yeah! Somebody give me a drink: I can't stand it 